\title{
Organization of virtual interaction in the context of the coronavirus pandemic
}

\section{Organización de la interacción virtual en el contexto de la pandemia de coronavirus}

\author{
Elena M. Voronova \\ Togliatti State University, Togliatti, Russia. \\ ORCID: https://orcid.org/0000-0002-0194-1289 \\ Anna V. Lapshova \\ Minin Nizhny Novgorod State Pedagogical University, Nizhny Novgorod, Russia. \\ ORCID: https://orcid.org/0000-0001-7017-3589

\section{Natalia V. Bystrova} \\ Minin Nizhny Novgorod State Pedagogical University, Nizhny Novgorod, Russia \\ ORCID: https://orcid.org/0000-0002-4310-6142

\section{Zhanna V. Smirnova} \\ Minin Nizhny Novgorod State Pedagogical University, Nizhny Novgorod, Russia. \\ ORCID: https://orcid.org/0000-0001-9950-9824

\section{Marina N. Bulaeva} \\ Minin Nizhny Novgorod State Pedagogical University, Nizhny Novgorod, Russia. \\ ORCID: https://orcid.org/0000-0002-9928-9451
}

\section{*Correspondence}

Email: ivannovadremova29@gmail.com

\section{Cite as:}

Voronova, E., Lapshova, A., Bystrova, N., Smirnova, Z., \&
Bulaeva, M. (2020). Organization of virtual interaction in the
context of the coronavirus pandemic. Propósitos y
$\begin{aligned} & \text { Representaciones, } 9 \\ & \text { http://dx.doi.org/10.20511/pyr2021.v9nSPE1.820 }\end{aligned}$

Voronova, E., Lapshova, A., Bystrova, N., Smirnova, Z., \& Bulaeva, M. (2020). Organization of virtual interaction in the http://dx.doi.org/10.20511/pyr2021.v9nSPE1.820 


\section{Summary}

The organization of the educational process should be carried out taking into account the epidemiological situation and following the requirements that are due to quarantine measures. The leadership of vocational schools is looking for ways to conduct classes in a safe environment, assessing the potential risks for teachers and students. Higher schools implement the possibilities of electronic technologies as a factor in ensuring the safety of subjects of the educational process for communication between students and teachers at a distance. The purpose of the article is to review the experience of organizing virtual interaction between students and teachers within the framework of e-learning during the spread of coronavirus infection. The article reveals the possibilities of electronic technologies that allow communicating at a remote distance. The preparation of students in critical conditions is carried out using various electronic means that promote active interaction. The results of the study reflect the opinion of students of higher educational institutions about the use of virtual interaction tools. The results obtained using the Likert scale allow us to say that the majority of the respondents are active participants in virtual interaction and are ready to continue to communicate using the presented means despite the existing difficulties.

Keywords: distance learning, coronavirus pandemic, professional education, virtual interaction.

\section{Resumen}

La organización del proceso educativo debe realizarse teniendo en cuenta la situación epidemiológica y siguiendo los requisitos que se deben a las medidas de cuarentena. El liderazgo de las escuelas vocacionales está buscando formas de impartir clases en un ambiente seguro, evaluando los riesgos potenciales para maestros y estudiantes. Las escuelas superiores implementan las posibilidades de las tecnologías electrónicas como factor para garantizar la seguridad de los sujetos del proceso educativo para la comunicación entre estudiantes y docentes a distancia. El objetivo del artículo es repasar la experiencia de organizar la interacción virtual entre estudiantes y profesores en el marco del e-learning durante la propagación de la infección por coronavirus. El artículo revela las posibilidades de las tecnologías electrónicas que permiten comunicarse a distancia. La preparación de los estudiantes en condiciones críticas se realiza utilizando diversos medios electrónicos que promueven la interacción activa. Los resultados del estudio reflejan la opinión de estudiantes de instituciones de educación superior sobre el uso de herramientas de interacción virtual. Los resultados obtenidos mediante la escala Likert nos permiten decir que la mayoría de los encuestados son participantes activos en la interacción virtual y están dispuestos a seguir comunicándose por los medios presentados a pesar de las dificultades existentes.

Palabras clave: educación a distancia, pandemia de coronavirus, educación profesional, interacción virtual.

\section{Introducción}

The spread of coronavirus infection has affected the economic and social life of many countries. One of the consequences of the pandemic was the accelerated spread of digital technologies in various areas of life, including vocational education. To comply with sanitary and epidemiological standards and preserve the health of subjects of the educational process, universities urgently implement the capabilities of various electronic technologies (Lutfullaev et al., 2020). Within the limits imposed by the government, the organization of interaction at a remote distance is one of the most urgent tasks facing educational institutions today. Restrictions related to COVID-19 have led to the active use of various programs that provide virtual interaction of subjects of the educational process, such as Microsoft Teams, Skype, Cisco Webex, Zoom, and others. Online communication allows teachers and students to communicate for classes, conferences, and consultations, both mass and individual (Felipe Arbeláez-Campillo et al., 2020), 
Arbeláez-Campillo, and Rojas-Bahamon, M. (2020). Most digital solutions provide a sufficient number of tools to help organize the effective learning process.

The crisis caused by COVID-19 caused the shortcomings of existing electronic technologies in the organization of distance learning. Among the main issues of organizing virtual interaction, researchers highlight the provision of high-quality access to the Internet, the provision of modern electronic equipment, which is designed to ensure an effective educational process (Klinkov, 2018). Also, among the difficulties in the field of education caused by the pandemic, it is worth noting that some technological solutions that provide virtual interaction of subjects of the educational process may face rejection from society since they relate to the issue of privacy. For the introduction and further effective use of electronic technologies for interaction between students and teachers, it is necessary to further improve information support from the government.

The technologies used are aimed at conducting classes with all participants of the educational process (Filchenkova, 2019). The practice of using them in the professional education system was already widespread, but with the full transition to distance learning, the load on electronic systems and subjects of the educational process increased, which required using the full potential of virtual interaction tools (Tsarapkina et al., 2019a). In such conditions, interaction acquires new specific features that require additional attention. Innovative e-learning platforms, applications, and systems are being introduced into the educational process. The demand for video streaming, video broadcasts, and collaboration services has increased dramatically.

With the spread of coronavirus infection, educational institutions have to act in critical conditions and choose appropriate strategies (Gladkov et al., 2019). This is a multi-faceted and complex process in which the organization of virtual interaction plays a significant role, so in this article, we address this issue.

\section{Theoretical framework}

The spread of coronavirus infection has revealed many problems that require modern operational solutions. The issue of organizing remote interaction is touched upon in the works of many scientists. Social distancing is designated as the main measure implemented to preserve the health of students. Social distancing refers to a set of non-drug anti-epidemic measures (Tsarapkina et al., 2019b) organized to prevent the spread of an infectious disease (Akhmetshin, 2020). Distancing is designed to minimize contact between infected and uninfected individuals (Pliushch, 2018). The risk of spreading coronavirus with social distancing is reduced (Vaskovskaya, 2018). Virtual interaction as a way to maintain social distance should be based on a systematic approach that involves a combination of interaction between teachers, students, psychologists, doctors and other specialists (Grigoriev et al., 2019).

Among the principles of organizing distance learning, it is worth highlighting: the formation of positive motivation of students to master the material at a remote distance and study it independently (Pinkovetskaia et al., 2020); regulation of the complexity and pace of the educational process by the teacher (Ivanov et al., 2020); introduction of a flexible learning mode; use of psycho-prophylaxis and stress tolerance methods in the distance educational process, which prevent the appearance of damaging consequences of stressful situations; providing students with the opportunity to study methods of self-diagnosis, self-correction and self-control (Birzhenyuk et al., 2020).

Virtual interaction has a large number of advantages, but in a critical situation and a complete transition to distance learning, students experience heavy loads (working in virtual space is accompanied by a strain on the visual analyzer, an increase in neuro-emotional tension, and affects the fatigue of the shoulder girdle muscles) (Aleksieienko-Lemovska, 2019) so researchers note that the duration of work in virtual space should be limited (Pichugina et al., 2019). Besides, the psychological burden is relieved by students performing independent work at a convenient 
time for them (Oros, 2018). They join groups and choose their own time to work on specific tasks (Eliseeva et al., 2020).

The features of virtual communication are multi-contact; content visualization; a combination of several forms of communication interactions.

Virtual interaction allows students and teachers to maintain communication while maintaining social distance and, as a result, contributes to the prevention of diseases (Kalinkina et al., 2017). However, the distance learning process raises questions that require operational solutions (Tishchenko, 2020). This includes the psychology of communication, increased load on students and teachers, technological problems, and others.

\section{Methodology}

The sample consists of 532 students enrolled in various courses in higher education institutions. For the study, the Likert scale was used, data for which were collected in electronic form for three months. The Likert scale is used to measure students' opinions and their attitude to the existing issue of organizing virtual interaction (Ponachugin et al., 2019). Answer options were set in the range from minimum to maximum, where the minimum corresponds to one, and the maximum corresponds to the number 5. the Likert Scale is displayed in text format as fully agree; partially agree; it's hard to say whether I agree or disagree; totally disagree. The text version is most convenient for respondents to understand it. Unlike simple questionnaires, the Likert scale allowed us to determine the degree of students' judgment. This scale was tested for reliability using Cronbach's alpha internal consistency measurements.

The studied population is students of higher educational institutions. The survey was conducted voluntarily. Statistical processing of data showed that out of the total number of respondents $-43 \%$ of male and $57 \%$ of female students, respectively, whose age varies from 18 to 36 years. The sample size and selection criteria ensure that the sample is representative.

At the same time, $100 \%$ of respondents have email, regularly use the Internet for training purposes, $93 \%$ use distance learning platforms, $78 \%$ of students use social networks to organize interaction for training purposes, $88 \%$ of students use network applications, $76 \%$ use various types of chats and are registered on forums, $42 \%$ use blogs for interaction, $87 \%$ of respondents participate in conferences held by teachers within Zoom and other network applications (for comparison, in 2019, the percentage of students, using Zoom features was significantly lower and was only $35 \%$ ).

\section{Results and discussion}

During the period of the spread of coronavirus infection, students were asked to switch to individual training to preserve their health. Many took advantage of this opportunity. At the same time, it was important to keep in touch with students to ensure the quality of the educational process. The organization of virtual interaction at the University was carried out using Google tools (Google Classroom, Google Meet, Google Drive, Google Sites, and others). Zoom and Skype capabilities were also used, and the electronic educational platform Moodle was used. With the advent of the second "wave" of infection and the complete transition of educational institutions to distance learning, the issue of organizing interaction with students has become particularly acute.

Virtual interaction is provided both with the help of well-known and long-used tools, and new ones introduced into the educational process for the first time. Moodle allows you to provide feedback between the teacher and the student, provides accessibility and visualization of educational information, storage of large amounts of data, promotes the development of group remote work in real time, activates the cognitive activity of students. Google Classroom is used 
for conducting online classes, allows you to show videos from YouTube and create surveys for regular verification of students. Students leave feedback and comments during classes. Google Meet is used for scientific conferences where students from different educational institutions take part and share their experiences. Zoom is a communication platform that is regularly used by teachers in the distance learning process. Zoom provides video conferencing with the ability to exchange messages and transmit content in real time. Participation in the conference in Zoom is possible from any device, so students are free to choose the appropriate gadget. Skype, unlike Zoom, does not provide such wide opportunities, so it is used by students individually among themselves while performing independent work and preparing for project protection.

The sample consists of students enrolled in various courses in higher education institutions. For the study, the Likert scale was used, data for which were collected in electronic form for three months.

Figure 1 shows the results of processing students' responses to the question of evaluating the effectiveness of the proposed remote interaction tools. Students had to Express their agreement with the statement "I would like to continue using the virtual interaction tools offered by the University, as they contribute to the full development of educational material".

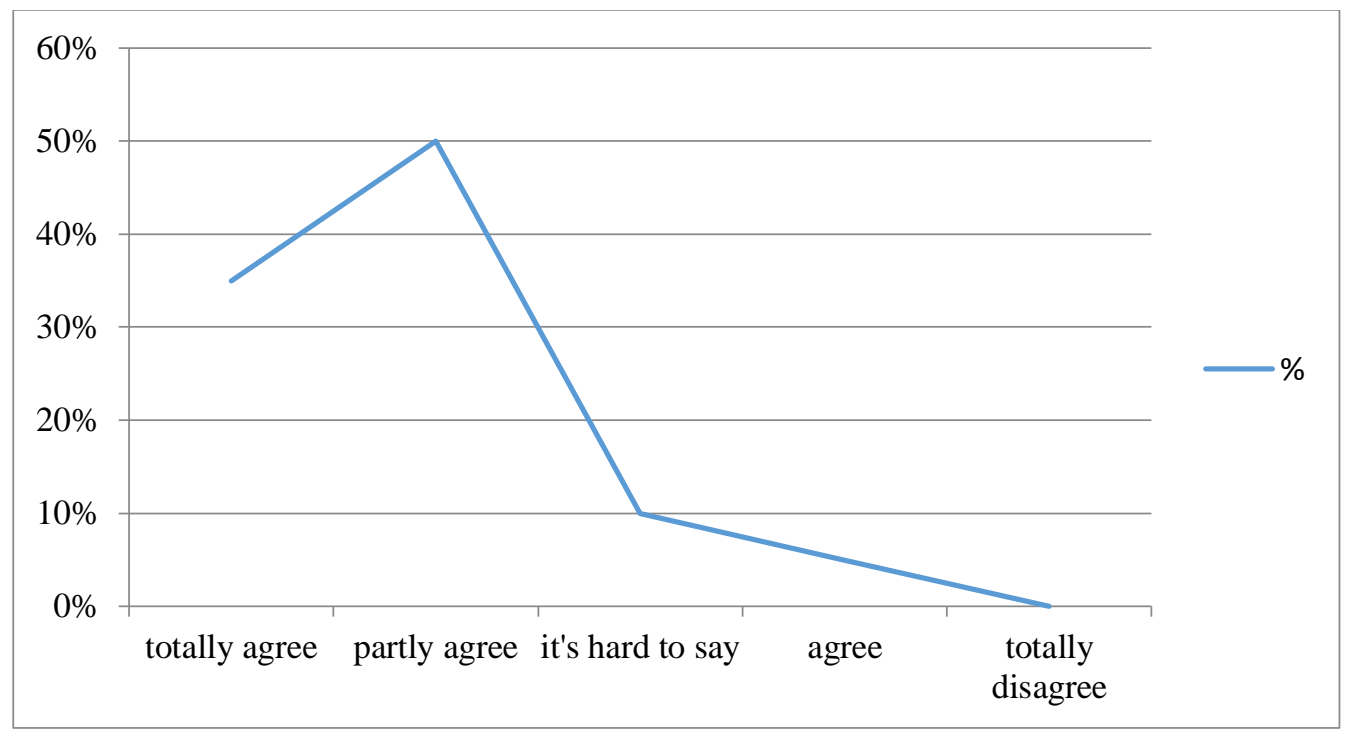

Fig. 1. Results of statistical processing of respondents' responses (as part of our research)

The results of processing the responses show that with the existing problems of implementing distance learning in the context of the spread of coronavirus infection, many students want to continue their education using the proposed tools and believe that they contribute to the full development of materials. Among the problems, students identify an acute lack of live communication. Social responsibility and compliance with health safety standards come to the fore, and virtual interaction tools help maintain social distancing by fulfilling their role. However, it is worth mentioning the psychological barriers that are manifested with renewed force during the spread of the second "wave" of coronavirus infection. The task of higher education institutions is to reduce these barriers by involving relevant specialists in the educational process. 
Table 1.

Shows a fragment of the statistical processing of data on students' perception of the prospects for using virtual interaction tools.

\begin{tabular}{|l|l|l|}
\hline No. & Answer & $\%$ \\
\hline 1 & Implementation of joint project activities & 80 \\
\hline 2 & Organization of virtual work communities & 76 \\
\hline 3 & Organization of independent activities in blogs & 85 \\
\hline 4 & Participation in a professional internship & 62 \\
\hline 5 & Portfolio creation & 90 \\
\hline 6 & Organization of an individual educational trajectory & 95 \\
\hline 7 & Have a part in international forums and webinars & 70 \\
\hline
\end{tabular}

Table 1. The results of statistical processing of data of answers to the question "Describe what the prospects are for using virtual learning tools? " (within the framework of our study)

Soon, students see the use of virtual interaction tools for building an individual educational trajectory together with teachers and fellow students, as well as for participating in international forums and webinars and participating in professional internships.

It is worth mentioning the problems that arise when implementing virtual interaction. Students note a lack of live communication. During the first "wave" of the COVID-19 pandemic, the transition to distance learning had a novelty effect, which motivated students to study online. Today, at the time of the growth of the second "wave" of coronavirus, new psychological barriers arise.

The emergency transition to distance learning and the organization of virtual interaction are forced measures that help preserve the health of students and teachers and prevent the spread of coronavirus infection. Virtual interaction contributes to the organization of independent work of students, their preparation for classes, work with additional information, various literary sources, and other activities. Students can complete individual projects by consulting with a teacher at a remote distance. Many types of work can be organized remotely. This ensures the maintenance of a full-fledged educational process during the pandemic and does not stop the work of educational organizations.

\section{Conclusions}

The organization of virtual interaction in the context of the spread of coronavirus infection requires the creation of adequate material and technical, resource base and training since the growth of the service audience raises some concerns related to the stability of the telecommunications infrastructure (Davydova, 2020).

We conducted a study that revealed the opinion of students of higher education institutions about the use of virtual interaction tools. The possibilities of virtual interaction tools allow you to include each student in the educational process and make it a full-fledged subject. The results obtained using the Likert scale suggest that the majority of respondents are active participants in virtual interaction and are ready to continue communicating using the Presented tools despite the existing difficulties. As limitations of the study, we highlight the use of a random sample of students, which still has sufficient and representative size.

In the future, we point out the need for further study of this issue. It is important to note the importance of expanding the sample. It requires not only high-quality technological support for the electronic interaction of students but also the introduction of regulations for remote interaction and changes in the teaching methodology. Currently, there are new tools that transform 
the educational process, which makes it necessary to further study this issue. Students become active subjects of the educational process and take part in its development in the new reality.

\section{References}

Akhmetshin, A.A. (2020). "Features of the activities of institutions of additional professional education in the context of the coronavirus pandemic in Russia". Innovation and Investment, No. 8, 239-232.

Aleksieienko-Lemovska, L.V. (2019). The activity approach as a basis for preschool teachers' methodological activities. Humanitarian Balkan Research, 3, 4(6), 10-14.

Arbeláez-Campillo, D.F., Rojas-Bahamon, M.J. (2020) "Pandemics in globalization times". Amazonia Investiga, 9(27), 3-4. doi: 10.34069/AI/2020.27.03.0.

Arbeláez-Campillo, D.F., Villasmil Espinoza, J.J. (2020). "Escenarios prospectivos de un nuevo orden internacional que se vislumbra luego de la pandemia COVID-19". Revista Telos, $22(3), 494-508$.

Birzhenyuk, G.M., Efimova, T.V. (2020). "Schering as a new landmark in education". Innovative development of vocational education, 2(26), 12-21.

Davydova, T. (2020). "The specifics of the organization of the educational process at the university in non-standard conditions". Production organizer, 2(28), 97-107.

Eliseeva, D.YU., Fedosov, A.YU., Agaltsova, D.V., Mnatsakanyan, O.L., kuchmezov, K. KH. (2020). "The evolution of artificial intelligence and the possibility of its application in cyber games". Amazonia Investiga, 9 (28), 123-129. https://amazoniainvestiga.info/index.php/amazonia/article/view/1043

Filchenkova, I.F. (2019). "Educational management of innovative activity of teachers as an object of pedagogical research". Vestnik of Minin University, 7(4), 3.

Grigoriev, S.G., Shabunina, V.A., Tsarapkina, Y.M., Dunaeva, N.V. (2019). "Electronic library system as a means of self-development of students of digital generation $\mathrm{Z}$ (on the example of studying the course "Basics of the counselor activity")". Scientific and technical libraries, 7, 78-99. 29.

Ivanov, M.S., Parnikova, T.A., Gulyaev, V.P., Petrov, N.V. (2020). "The activity approach implementation in the formation of students' general technical competencies. Amazonia Investiga, $9(26)$, 205-210. https://amazoniainvestiga.info/index.php/amazonia/article/view/1138

Kalinkina, E.G., Gorodetskaya, N.I. (2017). "Development of e-learning and distance learning technologies in the process of professional development of teachers". Nizhny Novgorod education, 1, 131-138.

Klinkov, G.T. (2018). "The specificity of manifestation of pedagogical communication as a special construct". Scientific Vector of the Balkans, 1, pp.51-52.

Lutfullaev, G.U., Lutfullaev, U.L., Kobilova, S.S., Neymatov, U.S. (2020). "Experience of distance learning in the context of the COVID-19 pandemic". Problems of pedagogy, 4 (49), 66-69. 
Oros, I.I. (2018). "The role of international connections in the development of the adult education system”. Humanitarian Balkan Research, 1, 57-59.

Pichugina, G.A., Bondarchuk, A.I. (2019). "Structure of the training case in the organization of the educational process". Humanitarian Balkan Research, 2(4), 5-7.

Pinkovetskaia, I.S., Arbeláez-Campillo, D.F., Rojas-Bahamón, M.J., Veas Iniesta, D. (2020). "Motivation of new entrepreneurs in modern economies". Amazonia Investiga, 9(29), 368-373 https://amazoniainvestiga.info/index.php/amazonia/article/view/1403

Pliushch, V.M. (2018). "Independent work of students as a factor of improving education quality". Balkan Scientific Review, 1, 69-71.

Ponachugin, A.V., Lapygin, Y.N. (2019). "Digital educational resources of the university: design, analysis and expertise". Vestnik of Minin University, 7(2), 5.

Tishchenko, A.S. (2020). "Assessment of the losses of educational organizations from a reduction in the volume of additional educational services to the population during a pandemic". Economic Development of Russia, 27(6), 73-79.

Tsarapkina, J.M., Petrova, M.M., Mironov, L.G., Morozova, I.M., Shustova, O.B. (2019b). "Robotics as a basis for Informatization of education in children's health camp". Amazonia Investiga, 8(20), 115-123. Available at: https://www.amazoniainvestiga.info/index.php/amazonia/article/view/70/48

Tsarapkina, J.M., Dunaeva, N.V., Kireicheva, A.M. (2019a). "Application of BYOD technology in education on the example of Lecture Racing mobile application". Informatics and Education, 9(308), 56-64.

Vaskovskaya, G.A. (2018). "Features of implementation of pedagogical technologies of profile training". Balkan Scientific Review, 1, 76-79. 